\title{
Research on Irrational Financing Behavior and Economic Consequences of New Energy Listed Companies
}

\author{
Jie $\mathrm{Lu}^{1} \&$ Yadong Wang ${ }^{2}$ \\ ${ }^{1}$ School of Management, Jiangsu University, China \\ ${ }^{2}$ School of Finance \& Economics, Jiangsu University, China \\ Correspondence: Jie Lu, School of Management, Jiangsu University, China. E-mail: lujie@mail.ujs.edu.cn
}

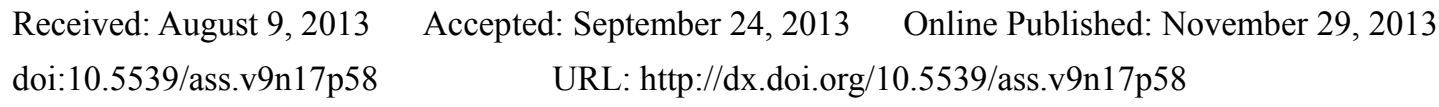

\begin{abstract}
Development of the new energy industry is crucial to China's future and local industrial rejuvenation. Meanwhile, irrational financing behavior will has negative effect on the sustainable development of listed company. As one of the emerging hi-tech enterprise, how to define the rationality of financing behavior is crucial to sustainable development of new energy industry. The article focuses on listed companies of new energy industries, analyzes irrational financing factors, and puts forward countermeasures.
\end{abstract}

Keywords: new energy, irrational, financing behavior, capital, structure

\section{Irrational Financing Behavior}

Irrational is relative to rational. Rational person hypothesis in economics is that people are fully rational, in order to pursue the maximal profit, however, this hypothesis is based on efficient market hypothesis (EMH). Simon found that people are limited rational due to external factors which make it difficult to realize the maximization of their own interests. Enterprise financing often uses the minimum cost to get the most money, eventually makes the maximization of the enterprise value. Nevertheless, the rational financing behavior is under the joint control of internal and external factors. The internal factors are easy to control, external factors restricted by the economic environment, culture, policy, regulations and other factors, however, have a larger uncertainty.

In order to realize the maximization of wealth for shareholders, listed companies certainly choose the financing mode, which has a lower capital weighted cost and is conducive to the sustainable development of the company. Since the debt financing can avoid tax and has a good effect on financial leverage, so it is the best choice of firm financing. In Britain and the United States, companies mostly follow the "pecking order theory" in the selection of financing, which means internal financing following external financing, while in external financing, debt financing is followed by stock financing. Such as the United States, stock financing is accounted for only about $0.8 \%$ of the sources of corporate funding. But for a long time, financing of listed companies in China is quite different from Western countries, and increasingly showing the "adverse selection" deviated from the financing low. At present, academic community mainly defines the financing order deviated from the pecking order theory as "irrational financing", what is excessively inclined to some financing and financing scale, service efficiency of fund, financing timing etc., and the emergence of irrational behavior is considered in condition of cognitive bias and the manager's overconfidence from the perspective of behavioral finance point. In a word, capital structure after irrational financing is deviation from the optimal capital structure.

\section{Irrational Financing Behavior of New Energy Listed Companies Inland and Analysis on Economic Consequences}

\subsection{The Current Situation and Questions of Irrational Financing Behavior in New Energy Listed Companies}

Energy is a powerful guarantee and foundation of economic development, which is the motive force of energy development in turn. The population and the consumption of energy continue to increase along with the continuous development of industry in the economic background of "energy-saving and emission-reduction" triggered by global warming present. Compared to conventional energy sources, new energy generally has the characteristics of less pollution and larger reserves. As one of the seven strategic emerging industries, the rapid development of China's new energy industry is inevitable. In recent ten years, our country has already formed the international competitive advantage in many fields of the development of new energy industry. Future 
development mainly will take the huge domestic market as backing to accelerate the promotion of innovation ability, while the irrational financing preference is always the "Achilles heel" lying in the sustainable development process of the new energy listed companies. At present, financing ways of new energy listed companies include issuing stock, introducing venture capital, issuing corporate bonds and bank loans. These channels are still unable to meet the needs of the rapid development of new energy industry of capital due to various reasons, and the financing mode remains biased, concrete analysis is as follows.

1) Pay attention to external financing than endogenous financing. This character is overall similar to listed companies in our country, but the new energy industry shows a stronger preference. This research has found that as a rising high-tech industry, the R\&D investment, the cost of production and sale is high for new energy industry, also the risk. As it is in the early stage of development, profitability is weak compared with other industries, leading to a low retained earnings. Therefore, the average rate of endogenous financing between 2009 and 2011 is only $5.6486 \%, 7.2503 \%, 5.7212 \%$ of new energy listed companies, far below the average of China's listed companies of $21.37 \%$. Meanwhile, the study on a sample of 50 sample enterprise has found that the minimum value of endogenous financing between 2009 and 2011 is- $25.5602 \%,-2.3256 \%,-15.4805 \%$, negative for 3, 2, 7 companies, and the highest value is only $22.8611 \%, 31.5446 \%, 44.3688 \%$. The endogenous financing ratio greater than $10 \%$ is only $10,13,9$ companies, accounting for $18.1819 \%, 23.6363 \%, 16.3636 \%$ for the statistical sample, indicating that the level of profitability of the industry is low, mainly rely on the external financing.

2) Short-term loan preference in bond financing. Compared with equity financing preference of China's listed companies, new energy listed companies do not show the obvious preference, the equity financing proportion in external financing is $55.2735 \%, 52.9706 \%, 47.6845 \%$ respectively between 2009 and 2011 . The proportion of equity financing is decreased illustrating that the leverage effect is actively used to expand financing scale. When further analyze the composition of debt financing, this paper uses the sample data and finds that short-term borrowing occupies an important position in debt financing, 54.356\%, 53.1515\%, 53.4529\%, respectively between 2009 and 2011, secondly the long-term borrowing, 41.9426\%, 42.3424\%, 35.5587\%, respectively and finally the bond financing, $3.7011 \%, 4.5065 \%, 10.9884 \%$ respectively. Thus it can be seen that new energy listed companies mainly rely on borrowing rather than bond financing, similar to China's aviation industry and real estate industry. Furthermore, the phenomenon of short-term debt become long-term is more serious which can be found through the footnotes to the financial statements of listed companies, and the repayment ability of short-term borrowing is worse. During the period of 2009-2011, number of companies issuing bonds is respectively 7, 10, and 19. Especially compared to equity financing, number of companies issuing stocks or shares over the three years is respectively 10,16, and 11. The funds raised by issuing or allotment of shares in three years is 16.3621 billion Yuan, 32.1906 billion Yuan, 21.4583 billion Yuan, and the funds raised by issuing bond is 16.7332 billion Yuan, 21.2852 billion Yuan, 41.6330 billion Yuan. It can be seen that enterprises prefer to equity financing rather than bond financing in the stock market.

3) Excessive financing and change the use of funds arbitrarily. Although there is only 7 of new energy companies publicly raised funds during 2009-2011, they are faced with excessive tendency to raise funds, which is similar to China's overall situation. The sum of funds principal-agent financing of 3 companies is 5602 million yuan in 2011, 12 companies raised funds a few years ago is up to 812.22 hundred million yuan, 6 companies used the raised funds in all 930 million yuan to add current capital, 5 companies changed the use of the raised funds totally 9378 million yuan. There was only 2 companies authorized agent financing of 202 million yuan in total in 2010, 11 companies raised funds a few years ago is 349.65 hundred million yuan, 2 companies used the raised funds in all 121.86 hundred million yuan to add current capital, 1 company changed the use of the raised funds totally 88 million yuan. There was 3 companies authorized agent financing of 1526 million yuan in total in 2009, explaining on one hand the new energy listed companies finance a large number of money, on the other hand they put a lot of money into the captical market for investment income to make up for lack of the industry which increase business risks, even some companies put $50 \%$ of raised funds into the project. The use efficiency of the fund is not high, and the phenomenon of arbitrarily change the use of raised funds is also very serious.

\subsection{Analysis on Economic Consequences of Irrational Financing Behavior of New Energy Listed Companies}

1) Venture capital is on a wait-and-see attitude and risk investment is seriously insufficient of new energy listed companies. Although most of the risk investment institutions focus on new energy as a key industry for investment, but the investment amount is very limited for new energy project from venture capital present. This is mainly due to two reasons, firstly are the technical barriers. Risk investment institutions know little about the technology research of new energy project, and concern about whether to recover the high investment, also have no confidence in achievement in scientific research and the market. Secondly are the existence barriers. 
Development status of China's new energy enterprises and capital market decide the venture capital is difficult to quit in a short period of time. On the one hand, the scale of China's new energy industry is limited, now it is unable to enter the industry mergers and acquisitions and shuffle period, so it cannot achieve capital exit though mergers and acquisitions. On the other hand, China's securities market is not mature, whether it is IPO or backdoor listing, there are some difficulties. Therefore the investment of venture capital to the new energy industry is still very limited.

2) The development of corporate bond market lies behind, limiting the bond financing of new energy listed companies. The indisputable fact is that China's capital market is lack of variety present. The development of the stock market has reached a certain scale, but development of the bond market, especially corporate bond market relative lag. The real corporate bonds in both variety and scale are very limited in China's bond market, only a few varieties like the short-term financing bonds and the switching company bonds. Therefore, the relative lag of the corporate bond market has restricted the scale of China's new energy enterprises to issue bonds in a certain extent.

3) The risk prevention awareness of commercial bank limits the size of loans to the new energy industry. At present, commercial banks are the main debt financing channels of China's enterprises. Under the consideration of preventing credit risks or obtaining short-term benefits, the banks have taken a cautious or limited credit policy for the new energy industry, not only the credit amount is less, the interest rate is up, and the guarantee condition is strict, leading the new energy enterprises in a relatively weak position in obtaining bank loans. From look on the whole, the credit investment of bank to new energy enterprises is serious insufficient.

\section{Research on Governance Countermeasures of Irrational Financing Behavior of New Energy Listed Companies}

\subsection{Increase Risk Investment Appropriately, Widen the Channel of the New Energy Finance}

This study argues that venture capital operation can meet the demand of new energy enterprises. From international successful cases, Hudson, clean energy companies obtain credit bank of Switzerland $\$ 300$ million in 2008, renewable energy investment banking at credit of Switzerland CEO John cavalier as a partners usually pay more attention to enterprise capital turnover and solvency, loans are mostly need collateral, and venture capital as equity capital, and bank credit capital of difference is that risk investment preference for high-risk projects, pay attention to corporate earnings and future growth, risk investment mainly covers in start-up stage of SMEs, to join Hudson, so as to realize win-win both sides with deposit. In general, most of new energy listed companies with high risk, while bank lending is mostly in security and risk aversion for first, more and better focused on enterprises with a higher benefits and a lower risk; Meanwhile, Bank and most of the high and new technology enterprise, works for equity investment, account for about $30 \%$ of corporate equity, investment horizon of at least 3 to 5 years, have introduced modern enterprise management mode. Thus, for the effective development of risk investment and withdrawal mechanism of venture investment barriers, need real second board market in our country, so that the venture capital exit quickly. At present, although the Shenzhen stock exchange has launched the small and medium-sized enterprises board, but the listed terms and there was no difference in the motherboard market, should lower the threshold of the new energy enterprises listed as soon as possible.

\subsection{Establish and Perfect the New Energy Fund}

This research thinks, should draw lessons from the current international popular oil fund operation technique, for example, Norway extracted from national finance income and tax each year set up by a percentage of the funds deposited in the oil fund, Azerbaijan with Mex services of benefit-sharing, risk-sharing collective investment system, mainly to new energy industry expansion funds, closed-end funds can be used commonly, duration for 10 to 15 years, by a government or big energy companies and non-bank financial institutions, the originator of registered capital icon and other countries are also established similar oil fund. Therefore, this research thinks, on the development of new energy, new energy fund set up by the government can effectively guide the big enterprise; the fund should generally include industrial investment fund and financial investment funds, etc., The former is a kind of equity investments in unlisted enterprises and provide management shall be not less than 200 million Yuan, the non-financial institutions registered capital shall be not less than 10 million RMB Yuan. As a result, new energy industry is extremely beneficial to orderly capital expansion and guide private capital into the new energy industry. At the same time, the financial investment funds, capital accumulation is a short-term investment as the main purpose, by the professional institutions manipulation of the securities funds to participate in futures, options and the international monetary market to arbitrage funds effectively. 


\subsection{Strengthening Governance Efficiency and Improving the Utilization of Funds}

How to use funds rationally and efficiently to improve the utilization of funds is one of the serious problems that the energy industry companies are facing. Therefore, first of all, they should use various types of financing instruments flexibly and synthetically, finance actively by issuance bonds to reduce operational risks arising from the large-scale short-term liabilities; Secondly, the state should improve our current weak efficient capital markets actively, not only from banks loans angle for the new energy industry companies to provide effective financial support, but also to develop innovative financing channels actively, diversify financing channels. Then they can provide investors with more investment choices, more importantly, it also can help new energy listed companies achieve healthy and sustainable development ultimately.

\section{References}

Flavin, T., \& O'Connor, T. (2010). The sequencing of stock market liberalization events and corporate financing decisions. Emerging Markets Review, (11). http://dx.doi.org/10.1016/j.ememar.2010.03.004

He, J. F. (2010). Research on Case of Debt Financing and Investment Behavior of Air Transport Enterprise. Friends of Accounting, (6).

Lu, Z. F., \& Gao, Q. (2003). Study on Financing Behavior of Listed Companies in China-Analyses Based on A Questionnaire. Accounting Research, (10).

Michael, C., \& Jensen, W. M. (1976). Theory of Firm: Managerial Behavior, Agency Costs, and Capital Structure. Journal of Financial Economics, (3), 305-360.

Olmos, L., \& Siok-JenLiong, S. R. (2012). On the selection of financing instruments to push the development of new technologies: Application to clean energy technologies. Energy Policy, (43). http://dx.doi.org/10.1016/j.enpol.2012.01.001

Paroma, S., \& Bulanb, L. T. (2011). Regulatory risk, market uncertainties, and firm financing choices: Evidence from U.S. Electricity Market Restructuring. The Quarterly Review of Economics and Finance, (5).

Zheng, L., \& Sun, Y. X. (2002). The Financial Structure and Corporate Governance. Economic Review, (4).

Zhou, X. H., \& Ma, L. (2008). Enterprise social capital, cultural orientation and exit intend to-based on localization psychology view of empirical research. Management world, (6), 109-117.

\section{Copyrights}

Copyright for this article is retained by the author(s), with first publication rights granted to the journal.

This is an open-access article distributed under the terms and conditions of the Creative Commons Attribution license (http://creativecommons.org/licenses/by/3.0/). 